\title{
Vermicompost as a Natural Adsorbent Material: Characterization and Potentialities for Cadmium Adsorption
}

\author{
Madson G. Pereira and Marco A. Z. Arruda* \\ Instituto de Química, Universidade Estadual de Campinas, CP 6154, 13084-971 Campinas - SP, Brazil
}

\begin{abstract}
Amostras de vermicomposto (material húmico) foram submetidas à caracterização por espectroscopia de infravermelho, difractometria de raios-X, termogravimetria, microscopia eletrônica, entre outras; adicionalmente, foi determinada a capacidade de troca catiônica (CTC). Empregou-se planejamento fatorial para estudar os mecanismos de interação da espécie $\mathrm{Cd}^{2+}$ com os sítios adsortivos do vermicomposto e, posteriormente, foi avaliada a máxima capacidade adsortiva de cádmio empregando isoterma de Langmuir. A caracterização revelou que o vermicomposto exibe CTC tão elevada quanto 72,9 meq por $100 \mathrm{~g}$, grande área superficial (substância porosa), grupos quelantes e máxima capacidade adsortiva para $\mathrm{Cd}\left(38,6 \mathrm{mg} \mathrm{g}^{-1}\right) \mathrm{em} \mathrm{pH} \mathrm{5,0.} \mathrm{Esta} \mathrm{potencialidade} \mathrm{foi} \mathrm{explorada} \mathrm{em}$ análises de amostras sintéticas e reais (água mineral) apresentando concentrações de cádmio próximas a $5 \mu \mathrm{g} \mathrm{L}{ }^{-1}$ e requerendo etapas de pré-concentração. Um fator de enriquecimento de 100 foi obtido.
\end{abstract}

Vermicompost (humic material) samples were submitted to characterization by infrared spectroscopy, $\mathrm{X}$-ray diffractometry, thermogravimetric analysis, electron microscopy etc. In addition, its cation exchange capacity (CEC) was determined. Factorial experiments were designed in order to elucidate the interaction mechanisms between $\mathrm{Cd}^{2+}$ and the adsorptive sites of vermicompost. The maximum adsorptive capacity for cadmium was evaluated by a Langmuir isotherm. The characterization revealed that vermicompost exhibits high CEC values ( $c a .72 .9$ meq per $100 \mathrm{~g}$ ), high surface area (porous material), chelating groups and a maximum adsorptive capacity for $\mathrm{Cd}\left(38.6 \mathrm{mg} \mathrm{g}^{-1}\right)$ at $\mathrm{pH}$ 5.0. This potential application was exploited in the analysis of synthetic and real (mineral water) samples with $\mathrm{Cd}$ concentrations of $c a 5 \mu \mathrm{g} \mathrm{L}^{-1}$, requiring a preconcentration step. An enrichment factor of 100 was attained.

Keywords: vermicompost, characterization, cadmium adsorption

\section{Introduction}

Humic substances comprise a number of organic compounds with complex molecular structure (aromatic rings, carbonyl groups, phenolic and alcoholic hydroxyl, among others). These substances are formed by chemical and microbial decomposition of animal and plant materials. ${ }^{1}$ The humification process occurs naturally in different environments such as soils, sediments, aquatic ecosystems (oceans, rivers and lakes) as well as in the upper plants. ${ }^{2}$ It should be noted that humification depends on several parameters, such as acidity, microbial population, nutrient concentrations, aeration and temperature. ${ }^{3}$

Due to its structural complexity, it is difficult to establish a classification of the humic substances and acceptable classification criteria are usually based on

*e-mail: zezzi@iqm.unicamp.br solubility properties. Thus, humic acids precipitate in acidic medium, humines are insoluble under both acidic and alkaline conditions and fulvic acids are soluble under both these conditions. ${ }^{4}$

Degradation of organic residues is usually a slow process, however other humification mechanisms may speed up it. Composting is frequently exploited, when conversion of fresh organic matter to substrates with a high degree of degradation is accomplished in a relatively short (usually a few months) period of time. ${ }^{1}$ During composting, the organic substrates are decomposed by microorganisms and the main products are $\mathrm{CO}_{2}, \mathrm{H}_{2} \mathrm{O}$, mineral ions and stabilized organic matter. ${ }^{3}$

Vermicomposting constitutes a special form of composting. It is accomplished when earthworms (mainly Lumbricus rubellus) metabolize and excrete a mixture of soil and organic matter (from agricultural, industrial and urban sources). In the digestive system of these worms, microorganisms are responsible for transforming some 
organic species (proteins, nucleic acids, fats, carbohydrates) into a more stable product (vermicompost). This product presents a high CEC, high humidity content, wide particle size distribution, high concentration of nutrients ( $\mathrm{Ca}, \mathrm{Mg}, \mathrm{Na}, \mathrm{K}, \mathrm{P}, \mathrm{S}, \mathrm{N}$ ) and a characteristic black colour due to the presence of humic substances. ${ }^{1,2}$

Despite the high CEC values, there are only a few studies about the characterization of vermicompost and about its application as a metal adsorbent. Thus, a characterization was performed to elucidate the interaction mechanisms between cadmium and vermicompost. After the characterization, the potentiality of cadmium adsorption was confirmed by carrying out analyses of $\mathrm{Cd}$ requiring a preconcentration step.

\section{Experimental}

\section{Instruments and apparatus}

For vermicompost characterization, a Shimadzu XRD 6000 X-ray diffractometer (Kyoto, Japan), a Perkin-Elmer FT-IR 1605 infrared spectrometer (Überlingen, Germany), a Perkin-Elmer PE 2400 elemental analyzer (Norwalk, USA), a TA Instruments TGA 2950 thermogravimetric analyzer (New Castle, USA) and a JEOL JMT-300 electron microscope (Tokyo, Japan) were used.

In order to establish the total cadmium concentration, as well as the extractable calcium and magnesium in the vermicompost, a Perkin-Elmer AAnalyst 300 flame atomic absorption spectrometer (Norwalk, USA), equipped with a deuterium lamp background correction system, was used. This instrument was also used for $\mathrm{Cd}$ determinations in the experiments involving factorial design and Langmuir isotherm. In addition, the instrument was used in the emission mode for the determination of extractable sodium and potassium in vermicompost, as well as potassium in mineral water samples.

In the preconcentration experiments, a Perkin-Elmer Analyst 600 graphite furnace atomic absorption spectrometer (Überlingen, Germany), equipped with a Zeeman-effect background correction system, was used to determine the cadmium content in synthetic aqueous solutions and in mineral water samples (after the enrichment process). The operating conditions were those recommended by the manufacturer for maximum sensitivity.

Hollow cathode lamps were employed as the radiation source for calcium $(\lambda=422.7 \mathrm{~nm})$ and magnesium $(\lambda=$ $285.2 \mathrm{~nm}$ ) determinations, whereas an electrodeless discharge lamp was used for cadmium $(\lambda=228.8 \mathrm{~nm})$.

Decomposition of the vermicompost was carried out using a QCI QW-3000 microwave oven (Mississauga,
Canada), equipped with temperature and pressure sensors and with a magnetron of $2450 \pm 13 \mathrm{MHz}$.

For pH measurements, a Digimed DM20 pH-meter (São Paulo, Brazil) was used.

Ultra-pure nitric acid employed in preconcentration procedures was obtained using a quartz sub-boiling still (Marconi, Piracicaba, Brazil).

A $3.4 \times 25 \mathrm{~cm}$ glass column was employed in the preconcentration experiments.

Standards, reagents and samples

All solutions were prepared with analytical reagentgrade chemicals (Merck, Darmstadt, Germany) and distilled/deionised water (Millipore, Mosheim, France). For adsorption experiments, a $1000 \mathrm{mg} \mathrm{L}^{-1} \mathrm{Cd}$ reference stock solution (in $1.6 \mathrm{~mol} \mathrm{~L}^{-1} \mathrm{HNO}_{3}$ ) based on $\mathrm{CdCl}_{2} \cdot \mathrm{H}_{2} \mathrm{O}$ was prepared. Working reference solutions (for FAAS calibrating purposes) with $0.5-2.0 \mathrm{mg} \mathrm{L}^{-1} \mathrm{Cd}$ were prepared daily by serial dilutions of the reference solution with $0.014 \mathrm{~mol} \mathrm{~L}^{-1} \mathrm{HNO}_{3}$.

Calcium, magnesium, sodium and potassium singleanalyte stock reference solutions (1000 $\mathrm{mg} \mathrm{L}^{-1}$ ) were prepared using $\mathrm{Ca}\left(\mathrm{NO}_{3}\right)_{2} \cdot 4 \mathrm{H}_{2} \mathrm{O}, \mathrm{Mg}\left(\mathrm{NO}_{3}\right)_{2} \cdot 6 \mathrm{H}_{2} \mathrm{O}, \mathrm{NaCl}$ and $\mathrm{KNO}_{3}$, respectively. Working reference solutions with $1.0-$ $5.0 \mathrm{mg} \mathrm{L}^{-1} \mathrm{Ca}, 0.1-0.5 \mathrm{mg} \mathrm{L}^{-1} \mathrm{Mg}$ and $1.0-10.0 \mathrm{mg} \mathrm{L}^{-1}$ $\mathrm{Na}$ or $\mathrm{K}$ were prepared daily by serial dilutions with $0.014 \mathrm{~mol} \mathrm{~L}^{-1} \mathrm{HNO}_{3}$.

Vermicompost samples were obtained from different regions of Minas Gerais and São Paulo States (Brazil). Two samples were collected in Tabuleiro do Pomba (MH) and Coimbra (SM), Minas Gerais. Sample XA was collected in Campinas, São Paulo.

For all experiments, except for those involving humidity evaluation, the vermicompost samples were dried in an oven $\left(60^{\circ} \mathrm{C}\right)$ for $24 \mathrm{~h}$ and the analyses were performed using particle sizes ranging from 75 to $150 \mu \mathrm{m}$.

For extractable calcium and magnesium determinations, a $10 \%(w / v) \mathrm{La}_{2} \mathrm{O}_{3}$ solution was used as releasing agent.

\section{Procedure}

For characterization of the three vermicompost samples (MH, SM and XA), different parameters, such as humidity, ash and total organic matter content (by thermogravimetric analysis), infrared spectroscopy, X-ray diffractometry, elemental composition, electron microscopy, $\mathrm{pH}$, exchangeable $\mathrm{Ca}, \mathrm{Mg}, \mathrm{Na}$ and $\mathrm{K}$, exchangeable and potential acidity, effective and potential cation exchange capacity (CEC) and total Cd content were evaluated. 
Thereafter, the XA sample was chosen for the experiments focusing on adsorption studies for $\mathrm{Cd}$ (factorial design, Langmuir isotherm and preconcentration). All experiments were made in triplicate, except those involving thermogravimetric analysis.

\section{Humidity}

The water content was determined by difference of vermicompost masses before and after submitting $10.0 \mathrm{~g}$ of fresh sample to $60^{\circ} \mathrm{C}$ for $24 \mathrm{~h}$.

\section{Ash and total organic matter content}

The ash and total organic matter content were obtained by heating the vermicompost samples from 20 to $980{ }^{\circ} \mathrm{C}$ $\left(10{ }^{\circ} \mathrm{C} \min ^{-1}\right.$ heating rate), respectively.

\section{Infrared spectroscopy, X-ray diffraction, elemental composition and electron microscopy}

The functional groups present in the vermicompost were characterized by Fourier-transform IR spectroscopy, using $\mathrm{KBr}$ discs to prepare the vermicompost samples. The spectral range varied from 4000 to $400 \mathrm{~cm}^{-1}$.

For X-ray diffraction, the samples were exposed to $\mathrm{X}$ rays $(\lambda=1.54060 \AA)$ with the $2 \theta$ angle varying within 5 and $50^{\circ}$. The applied voltage and current were $40 \mathrm{kV}$ and $30 \mathrm{~mA}$, respectively.

Carbon, nitrogen and hydrogen determinations used an elemental analyzer while for electron microscopy, vermicompost samples were covered with a thin layer of gold and an electron acceleration voltage of $20 \mathrm{kV}$ was applied.

\section{pH measurement}

The procedures described in this section as well as those indicated in several subsequent sections were adopted or modified from Pace et al..$^{5}$

For $\mathrm{pH}$ determination, $10.0 \mathrm{~g}$ of the vermicompost were shaken with $25 \mathrm{~mL}$ of a $1.0 \mathrm{~mol} \mathrm{~L}^{-1} \mathrm{KCl}$ solution for $1 \mathrm{~min}$. The samples were then allowed to rest for $1.0 \mathrm{~h}$. Afterthat, the samples were shaken during $1.0 \mathrm{~min}$ and the $\mathrm{pH}$ of the resulting suspension was potentiometrically determined.

\section{Exchangeable $\mathrm{Ca}, \mathrm{Mg}, \mathrm{Na}$ and $\mathrm{K}^{5}$}

The vermicompost $(3.0 \mathrm{~g})$ was shaken for $1.0 \mathrm{~h}$ with $75 \mathrm{~mL}$ of a $1.0 \mathrm{~mol} \mathrm{~L}^{-1} \mathrm{KCl}$ solution for $\mathrm{Ca}$ and $\mathrm{Mg}$ extraction or with $75 \mathrm{~mL}$ of $0.05 \mathrm{~mol} \mathrm{~L}^{-1} \mathrm{HCl}$ for $\mathrm{Na}$ and $\mathrm{K}$ extraction. After shaking, a period of $16 \mathrm{~h}$ for sedimentation was needed to complete both extractions. $\mathrm{Ca}$ and $\mathrm{Mg}$ concentrations in the liquid phase were then determined by FAAS. For exchangeable $\mathrm{Na}$ and $\mathrm{K}$, the FAAS spectrometer was operated in the emission mode.

\section{Exchangeable or potential acidity ${ }^{5}$}

The species related to exchangeable or potential acidity were extracted by shaking $3.0 \mathrm{~g}$ of vermicompost with $75 \mathrm{~mL}$ of either a $1.0 \mathrm{~mol} \mathrm{~L}^{-1} \mathrm{KCl}$ solution (for exchangeable acidity studies), or an acetate buffer solution, $\mathrm{pH} 7$ (potential acidity studies), for $1 \mathrm{~h}$. Thereafter, a period of $16 \mathrm{~h}$ for sedimentation was needed. In the experiments related to exchangeable acidity, $25 \mathrm{~mL}$ of the supernatant were selected and titrated with a $0.025 \mathrm{~mol} \mathrm{~L}^{-1} \mathrm{NaOH}$ solution; bromothymol blue was used as indicator. For potential acidity evaluation, with the same titrant, the end point was determined using phenolphthalein.

\section{Effective and potential $C E C^{5}$}

The effective $\mathrm{CEC}$ value $\left(\mathrm{CEC}_{\text {eff }}\right)$ was calculated as the sum of the exchangeable acidity plus the exchangeable $\mathrm{Ca}, \mathrm{Mg}, \mathrm{K}$, and $\mathrm{Na}$ contents. In addition, the potential $\mathrm{CEC}$ value $\left(\mathrm{CEC}_{\mathrm{pot}}\right)$ was calculated as the sum of the exchangeable $\mathrm{Ca}, \mathrm{Mg}, \mathrm{K}$, and $\mathrm{Na}$ contents plus the results obtained for potential acidity.

\section{Total Cd content}

In this experiment $600 \mathrm{mg}$ of vermicompost samples were decomposed through an acidic microwave-assisted decomposition procedure ${ }^{6}$ using concentrated $\mathrm{HCl}, \mathrm{HNO}_{3}$ and $\mathrm{HF}$ acids (3:1:2 volumetric ratio, $15 \mathrm{~mL}$ total volume). After that, the digests were dried almost to dryness and the volume made up to $25 \mathrm{~mL}$ with $0.014 \mathrm{~mol} \mathrm{~L}^{-1} \mathrm{HNO}_{3}$. For $\mathrm{HF}$ elimination, $c a$. $300 \mathrm{mg} \mathrm{H}_{3} \mathrm{BO}_{3}$ were added to the samples.

After sample decomposition, cadmium concentrations were determined by FAAS.

\section{Factorial design for cadmium adsorption}

These experiments were carried out for optimizing the $\mathrm{pH}$ and the shaking time interval for cadmium adsorption by the vermicompost. A factorial design ${ }^{7}$ was chosen because this chemometric approach may consider simultaneously both investigated variables (factors): $\mathrm{pH}$ and shaking time. Thus, interaction effects are considered, and a more reliable interpretation of results is possible. It is important to note that factorial design was also necessary to construct the Langmuir isotherm. 
For factorial design, a $60 \mathrm{mg} \mathrm{L}^{-1}$ cadmium solution was prepared from the $1000 \mathrm{mg} \mathrm{L}^{-1}$ stock reference cadmium solution. The $\mathrm{pH}$ of these solutions were adjusted at 2.0, 4.0 or 6.0 by adding $0.1 \mathrm{~mol} \mathrm{~L}^{-1} \mathrm{HNO}_{3}$ or $\mathrm{NaOH}$ whenever necessary. The shaking times $(5.0,32.5$ or $60 \mathrm{~min})$ were tested for each $\mathrm{pH}$ condition. According to the factorial design employed $\left(3^{2}\right)$, nine combinations were made (Table 1). Twenty-seven assays were carried out (3 replicates for each combination). According to adaptations from Slavek et al., ${ }^{8}$ for each assay, $20 \mathrm{mg}$ of vermicompost were shaken by a magnetic stirrer with $40 \mathrm{~mL}$ of $60 \mathrm{mg} \mathrm{L}^{-1}$ cadmium solution. After this step, the samples were centrifuged at $3000 \mathrm{rpm}$ for $20 \mathrm{~min}$. Suitable liquid phase volumes (according to the required dilution) were transferred to $25 \mathrm{~mL}$ volumetric flasks and the volume was completed with 0.014 mol L-1 $\mathrm{HNO}_{3}$ solution. The cadmium concentrations were determined by FAAS.

Table 1. Combinations used in the factorial design $\left(3^{2}\right)$ for $\mathrm{Cd}$ adsorption studies in vermicompost ${ }^{\mathrm{a}}$

\begin{tabular}{crc}
\hline Combination & $\mathrm{pH}$ & Shaking time \\
\hline 1 & -1 & -1 \\
2 & 0 & -1 \\
3 & 1 & -1 \\
4 & -1 & 0 \\
5 & 0 & 0 \\
6 & 1 & 0 \\
7 & -1 & 1 \\
8 & 0 & 1 \\
9 & 1 & 1 \\
\hline
\end{tabular}

${ }^{a}$ Numbers $-1,0$ and 1 correspond to $\mathrm{pH}$ levels of 2, 4, 6 and shaking times of $5,32.5,60 \mathrm{~min}$, respectively.

\section{Langmuir isotherm for cadmium}

Cadmium saturation in the vermicompost was established by a Langmuir isotherm. To this end, $40 \mathrm{mg}$ of vermicompost were mixed with $40 \mathrm{~mL}$ of different cadmium solutions $\left(10,50,200,600,800\right.$, and $\left.1000 \mathrm{mg} \mathrm{L}^{-1}\right)$. The acidity and shaking time were defined as $\mathrm{pH} 5.0$ and 5.0 min, respectively, from experiments performed in the Factorial design section. After shaking, samples were centrifuged at $3000 \mathrm{rpm}$ for $20 \mathrm{~min}$ and suitable supernatant volumes were transferred to $50 \mathrm{~mL}$ volumetric flasks and diluted with $0.014 \mathrm{~mol} \mathrm{~L}^{-1} \mathrm{HNO}_{3}$ solution. Cadmium concentrations were determined for these solutions.

\section{Cadmium preconcentration in vermicompost columns}

This experiment was made by passing $1000 \mathrm{~mL}$ of synthetic or real samples $\left(10 \mathrm{~mL} \mathrm{~min}^{-1}\right)$ at $\mathrm{pH} 5.0$ through the vermicompost columns. For the synthetic aqueous sample (5.0 $\left.\mu \mathrm{g} \mathrm{Cd} \mathrm{L}^{-1}\right), 60 \mathrm{mg}$ vermicompost were used whereas for the real sample (mineral water spiked with cadmium up to 5.0 $\left.\mu \mathrm{g} \mathrm{L}^{-1}\right), 120 \mathrm{mg}$ of vermicompost were needed. The mineral water employed in this experiment (Genuína brand, Lindóia SP, Brazil) was obtained at a local market.

After preconcentration, the cadmium retained was desorbed by adding $10 \mathrm{~mL}$ of a $1.0 \mathrm{~mol} \mathrm{~L}^{-1} \mathrm{HNO}_{3}$ solution. In the elution step, the flow-rate was maintained at $10 \mathrm{~mL}$ $\mathrm{min}^{-1}$. Cadmium in the eluent solutions was determined by FAAS.

After preparing synthetic samples and enriched mineral water, the cadmium concentration in these samples was also measured by graphite furnace atomic absorption spectrometry (GFAAS).

\section{Results and Discussion}

The X-ray diffractograms (Figures 1a-c) revealed the presence of $\mathrm{SiO}_{2}$ in the vermicomposts. This mineral was predominant in this material, whereas other minerals occurred only at trace levels, thus making identification difficult. It should be emphasized that other peaks were also associated to $\mathrm{SiO}_{2}$ but with different inter-planar distances. The material in Figure $1 \mathrm{~b}$ presents an amorphous characteristic. The main peak of $\mathrm{SiO}_{2}$ is shown in Figures 1 a-c.

The initial thermal decompositions of organic matter (see thermogravimetric curves, Figures 2a-c) were similar for the different samples: $245{ }^{\circ} \mathrm{C}(\mathrm{MH}), 239^{\circ} \mathrm{C}(\mathrm{SM})$ and $243{ }^{\circ} \mathrm{C}$ (XA). Otherwise, the final decomposition temperature of organic matter, presented a pronounced difference between XA and the other vermicomposts: $500{ }^{\circ} \mathrm{C}(\mathrm{MH}), 479{ }^{\circ} \mathrm{C}(\mathrm{SM})$ and $645^{\circ} \mathrm{C}(\mathrm{XA})$, indicating a possible differentiation in the structure of the organic matter in these samples.

The results for total organic matter (TOM) were established by considering the differences of the masses at the initial and final decomposition temperatures. The results obtained matched the literature information., ${ }^{9,10}$ According to these literature, samples collected in Juiz de Fora and São Carlos, presented results of TOM as 47.7 and $31.5 \% \mathrm{~m} / \mathrm{m}$, respectively. Results for humidity, ash, total organic matter and elemental composition of vermicompost samples are presented in Table 2.

According to the literature, ${ }^{9}$ similar values for ash contents were observed for bovine manure vermicompost. The ash content for the sample collected in Juiz de Fora was $47.3 \% \mathrm{~m} / \mathrm{m}$. This value reveals the complexity of the raw material employed in vermicompost production.

Products obtained by the vermicomposting process present high humidity levels. ${ }^{1}$ In this way, results obtained in the humidity tests (from 56.2 to $59.8 \%$ ) are in agreement with this affirmation. 

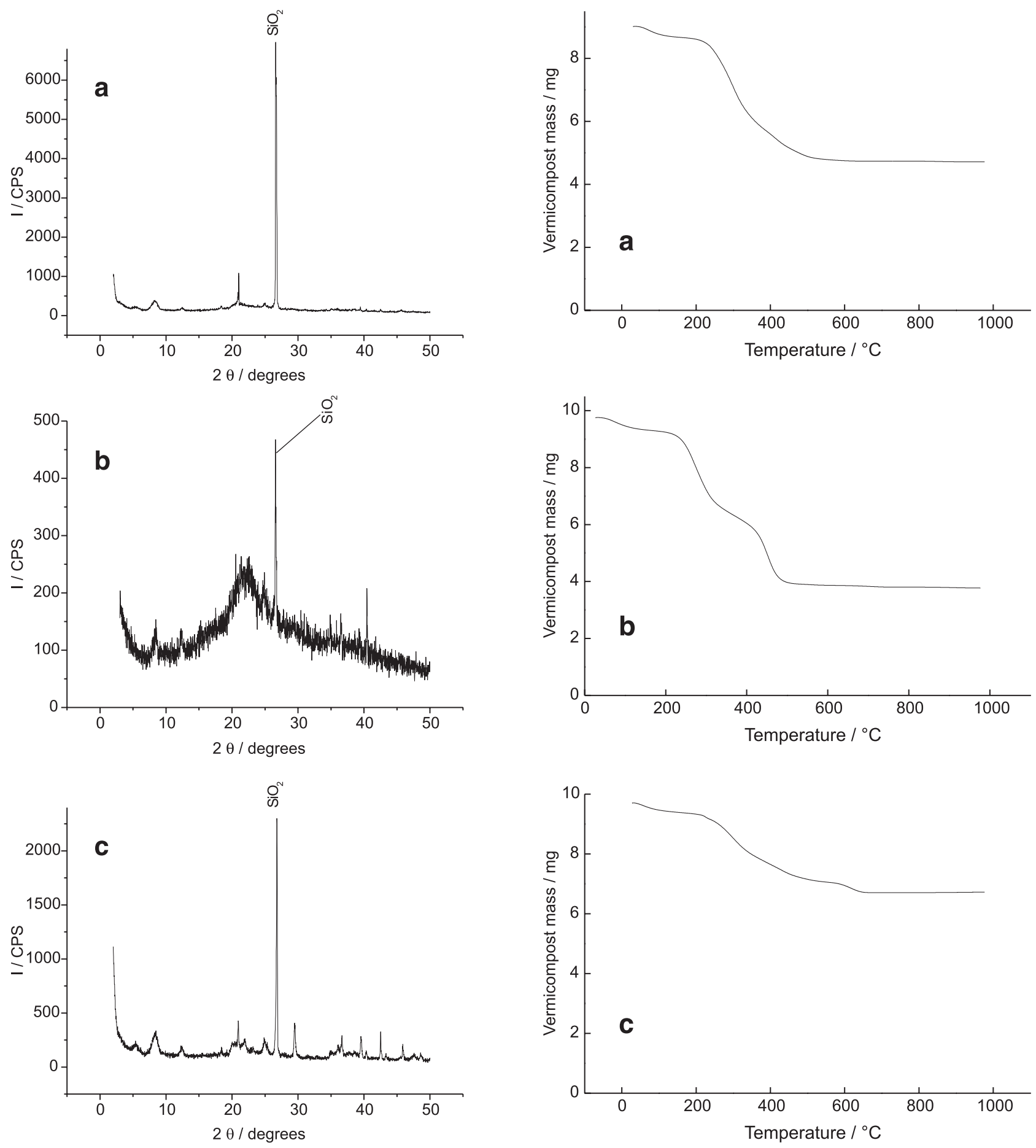

Figure 1. X-ray diffractograms of (a) MH, (b) SM and (c) XA vermicompost samples. For details, see text.

Figure 2. Thermogravimetric graphics of (a) MH, (b) SM and (c) XA vermicompost samples.

Table 2. Humidity, ash, total organic matter (TOM) and elemental composition $(\mathrm{C}, \mathrm{N}$ and $\mathrm{H})$; $\mathrm{n}=3$. For sample identification, see text

\begin{tabular}{lcccccc}
\hline Sample & Humidity $(\%)$ & Ash $^{\mathrm{a}}(\%)$ & TOM $^{\mathrm{a}}(\%)$ & $\mathrm{C}(\%)$ & $\mathrm{N}(\%)$ & $\mathrm{H}(\%)$ \\
\hline MH & $59.8 \pm 0.3$ & 53.7 & 41.2 & $17.1 \pm 0.1$ & $2.0 \pm 0.1$ & $3.0 \pm 0.1$ \\
SM & $56.2 \pm 0.1$ & 41.1 & 53.5 & $33.2 \pm 1.0$ & $2.3 \pm 0.1$ & $5.0 \pm 0.2$ \\
XA & $57.9 \pm 1.3$ & 68.8 & 27.0 & $10.4 \pm 0.2$ & $0.7 \pm 0.1$ & $1.8 \pm 0.1$ \\
\hline
\end{tabular}

${ }^{\mathrm{a}}$ without replicates. 
For all vermicompost samples, the potential acidity results were higher than those related to exchangeable acidity (Table 3). This can be explained in view of the organic matter present in vermicompost, whereas at $\mathrm{pH} 7$ (the best $\mathrm{pH}$ for potential acidity), several acidic groups of organic matter are dissociated and the titrated acidity comprises the sum of exchangeable acidity (due to $\mathrm{Al}^{3+}$ hydrolysis) plus the hydrogen concentration originating from organic matter dissociation. This is an interesting behavior related to the adsorption phenomena of metallic species at higher $\mathrm{pH}$ values.

Table 3. Exchangeable acidity (EA), potential acidity (PA) and $\mathrm{pH}$ values $(n=3)$. For sample identification, see text

\begin{tabular}{lclc}
\hline Sample & \multicolumn{1}{c}{$\mathrm{PA}^{\mathrm{a}}$} & \multicolumn{1}{c}{$\mathrm{EA}^{\mathrm{a}}$} & $\mathrm{pH}$ \\
\hline $\mathrm{MH}$ & $4.4 \pm 0.2$ & $0.9 \pm 0.1$ & $5.8 \pm 0.2$ \\
SM & $4.1 \pm 0.1$ & 0.0 & $7.8 \pm 0.3$ \\
$\mathrm{XA}$ & $3.2 \pm 0.1$ & $1.1 \pm 0.1$ & $5.7 \pm 0.1$ \\
\hline
\end{tabular}

${ }^{\mathrm{a}}$ Values expressed in meq per $100 \mathrm{~g}$

The exchangeable cation values (Table 4) reveal the differences among the three investigated vermicompost samples, which are probably due to the origin of these samples.

Table 4. $\mathrm{Ca}, \mathrm{Mg}, \mathrm{K}$ and $\mathrm{Na}$ exchangeable concentrations $(\mathrm{n}=3)$, expressed in meq per $100 \mathrm{~g}$. For sample identification, see text

\begin{tabular}{lcrcc}
\hline Sample & $\mathrm{Ca}$ & \multicolumn{1}{c}{$\mathrm{Mg}$} & $\mathrm{K}$ & $\mathrm{Na}$ \\
\hline $\mathrm{MH}$ & $32.4 \pm 2.0$ & $9.2 \pm 0.7$ & $1.5 \pm 0.1$ & $1.6 \pm 0.1$ \\
SM & $20.9 \pm 1.0$ & $18.4 \pm 0.6$ & $4.7 \pm 0.2$ & $6.4 \pm 0.1$ \\
XA & $52.2 \pm 3.3$ & $1.5 \pm 0.1$ & $6.7 \pm 0.4$ & $9.3 \pm 0.3$ \\
\hline
\end{tabular}

The vermicompost samples presented CEC values higher than those related to soil materials (Table 5). This can be confirmed comparing CEC results (from 45.6 to 72.9 meq per $100 \mathrm{~g}$ ) with those already obtained (24.1 meq per $100 \mathrm{~g}$ ) from Philippine agricultural soils. ${ }^{11}$ It is important to stress that higher CEC values of vermicompost correspond to a higher capacity to retain metals by adsorption processes. In this way, the XA vermicompost was selected for the adsorption experiments due to the highest CEC values obtained (Table 5).

Table 5. Effective cationic exchange capacity $\left(\mathrm{CEC}_{\text {eff }}\right)$ and potential cationic exchange capacity $\left(\mathrm{CEC}_{\mathrm{pot}}\right)$. Values expressed in meq per $100 \mathrm{~g}$. For sample identification, see text

\begin{tabular}{lcc}
\hline Sample & $\mathrm{CEC}_{\text {eff }}$ & $\mathrm{CEC}_{\text {pot }}$ \\
\hline $\mathrm{MH}$ & $45.6 \pm 2.1$ & $49.1 \pm 2.1$ \\
$\mathrm{SM}$ & $50.4 \pm 1.2$ & $54.5 \pm 1.2$ \\
$\mathrm{XA}$ & $70.8 \pm 3.3$ & $72.9 \pm 3.3$ \\
\hline
\end{tabular}

The infrared spectra (Figures 3a-c) reveal the presence of groups associated with organic matter, which can be considered as potential sites for binding with metallic species. The bands observed between 3500 to $3000 \mathrm{~cm}^{-1}$ indicate the occurrence of the characteristic absorption of $\mathrm{N}-\mathrm{H}$ from amines and amides as well as alcoholic and phenolic hydroxyls and carboxylic acids (Figure 3a: 3445.7 $\mathrm{cm}^{-1}$; Figure $3 \mathrm{~b}: 3433.9 \mathrm{~cm}^{-1}$; Figure $\left.3 \mathrm{c}: 3527.0 \mathrm{~cm}^{-1}\right)$. In the 3000 to $2800 \mathrm{~cm}^{-1}$ region, the absorption was mainly
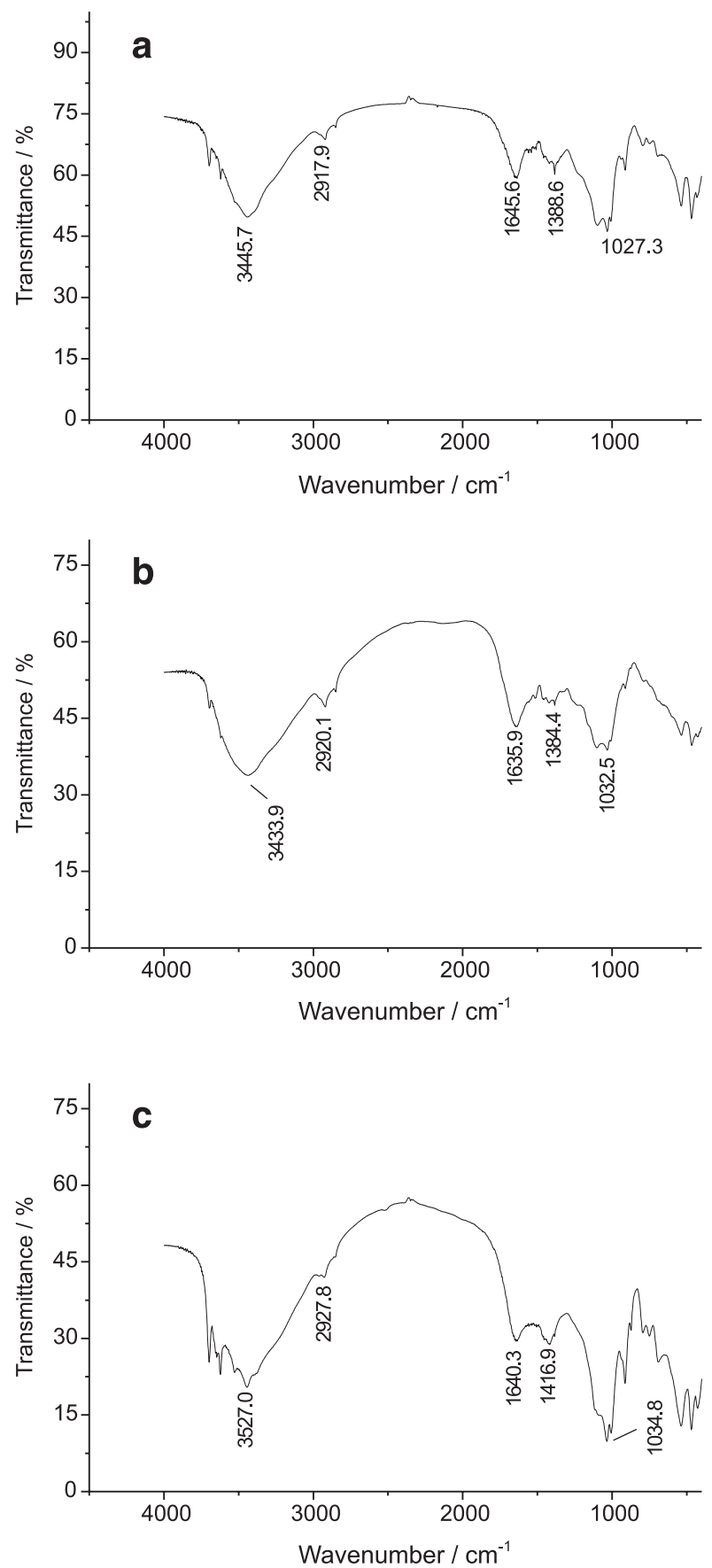

Figure 3. Infrared spectra of (a) $\mathrm{MH}$, (b) SM and (c) XA vermicompost samples. For details, see text. 
assigned to the $\mathrm{C}-\mathrm{H}$ bond from aliphatic groups (Figure 3a: $2917.9 \mathrm{~cm}^{-1}$; Figure 3b: $2920.1 \mathrm{~cm}^{-1}$; Figure 3c: $2927.8 \mathrm{~cm}^{-1}$ ). Between 2000 to $1000 \mathrm{~cm}^{-1}$, the absorption can be attributed to the presence of $\mathrm{C}-\mathrm{O}$ and $\mathrm{C}=\mathrm{O}$ bands ${ }^{12}$ (Figure 3a: 1027.3, 1388.6, $1645.6 \mathrm{~cm}^{-1}$; Figure 3b: 1032.5, $1384.4,1635.9$ $\mathrm{cm}^{-1}$; Figure 3c: $1034.8,1416.9,1640.3 \mathrm{~cm}^{-1}$ ).

The importance of total cadmium determinations in vermicompost is related to the natural concentration of this element in the material. After microwave-assisted decomposition of three vermicompost samples, measurements revealed that total $\mathrm{Cd}$ concentrations were lower than the detection limit of FAAS $\left(0.08 \mathrm{mg} \mathrm{L}^{-1}\right)$. These results indicated the low concentration of naturally occurring cadmium present in the vermicompost.

Results of the factorial design are indicated in Table 6 and, according to the mathematical treatment given by Matthias, ${ }^{7}$ a response surface (Figure 4a) was obtained from these data. The surface reveals optimized values near to 0.5 on the $\mathrm{pH}$ axis for the cadmium adsorption process. It is important to note that this value is normalized, therefore it is necessary to find the corresponding value on the true $\mathrm{pH}$ scale (it is near 5); this conversion is possible using literature procedures. ${ }^{7}$ The equation obtained from the data shown in Table $6\left[\%\right.$ Cd adsorption $\left.=36.97+12.25 \mathrm{pH}-15.00 \mathrm{pH}^{2}\right]$ was taken into consideration in order to achieve the response surface (Figure 4a). The parameter agitation time is not shown in this equation because the error associated to this variable was higher than the coefficient related to it. This Figure also indicates that $\mathrm{Cd}$ adsorption was independent of the shaking time. These results can be explained in terms of the predominance of cationic exchange that may indicate that equilibrium between the $\mathrm{Cd}(\mathrm{II})$ content in the liquid and in the solid phases is rapidly attained. Another response surface representation comprises contour graphics (Figure
Table 6. Data from factorial design

\begin{tabular}{rcc}
\hline $\mathrm{pH}^{\mathrm{a}}$ & Shaking time $^{\mathrm{a}}$ & Cd adsorption $(\%)^{\mathrm{b}}$ \\
\hline-1 & -1 & $7.30 \pm 0.58$ \\
0 & -1 & $38.68 \pm 0.39$ \\
1 & -1 & $34.01 \pm 2.38$ \\
-1 & 0 & $11.61 \pm 1.10$ \\
0 & 0 & $34.84 \pm 1.05$ \\
1 & 0 & $34.64 \pm 1.39$ \\
-1 & 1 & $9.06 \pm 0.27$ \\
0 & 1 & $34.48 \pm 2.07$ \\
1 & 1 & $32.22 \pm 1.29$ \\
\hline
\end{tabular}

a The values $-1,0$ and 1 as in Table 1 ; ${ }^{b}$ Mean of 3 replicates \pm standard deviation.

4b) that are obtained when constant values are attributed to dependent variables. In this specific situation, the parallel lines indicate that any variation of agitation time (within the studied interval) does not modify the cadmium adsorption, but the $\mathrm{pH}$ value strongly influences the analytical response. From this contour graphic, it is also possible to verify that the best $\mathrm{pH}$ for cadmium adsorption is attained near to 0.5 (normalized scale) or 5.0 ( $\mathrm{pH}$ scale).

Electron micrographies of vermicompost are shown in Figures 5a-c. These figures show a surface area with an irregular morphology as well as a high number of pores. This morphology can corroborate to high CEC values, such as those obtained, due to the high number of sites for metal adsorption.

The isotherm in Figure 6 shows a tendency towards saturation. This kind of isotherm is classified as Langmuir because it follows the mathematical model indicated by equation $1:^{13}$

$q M=a \cdot b \cdot C_{e q} M \cdot\left(1+a \cdot C_{e q} M\right)^{-1}$

where $\mathrm{qM}=$ quantity of adsorbed metal in vermicompost
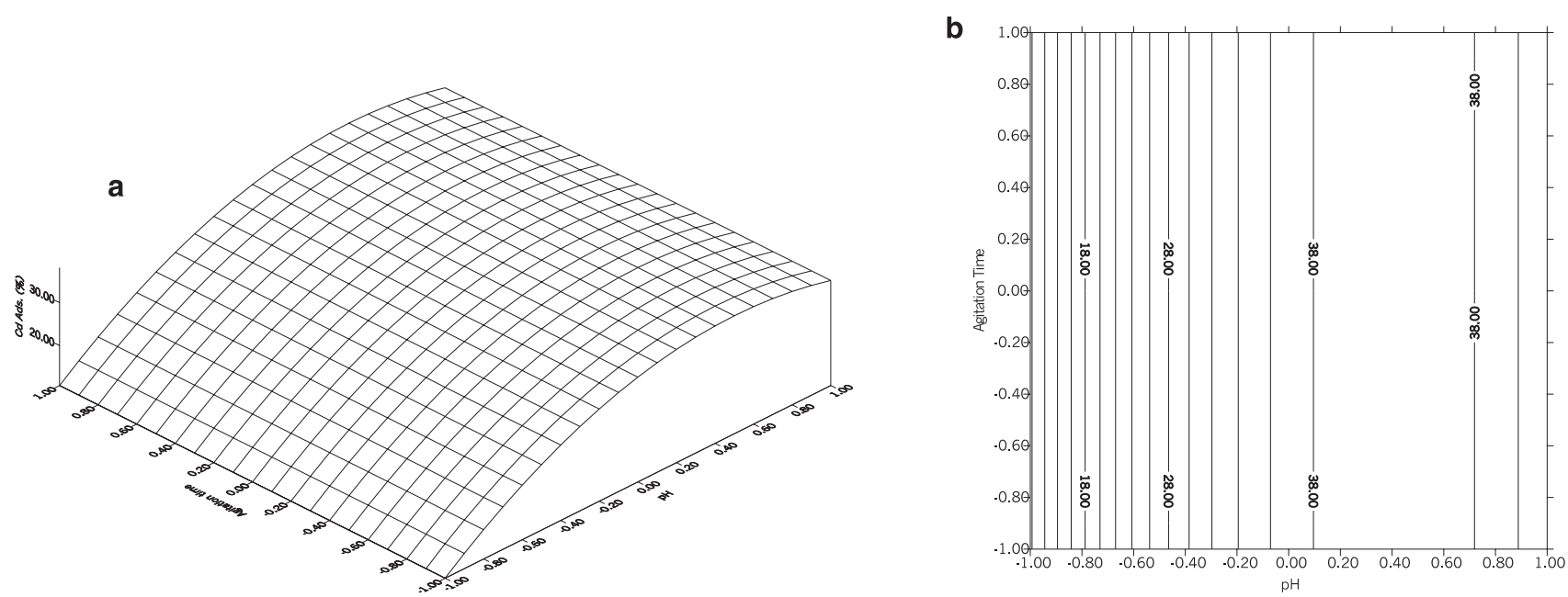

Figure 4. a) Cadmium adsorption (\%) obtained by factorial design for XA vermicompost relating agitation time and pH. The values of time (from 1.00 to +1.00 ) are related to $5-60 \mathrm{~min}$ of agitation and the $\mathrm{pH}$ values (from -1.00 to +1.00 ) are related to $2-6$; b) Contour graph related to Figure 4a. Numbers correspond to Cd adsorption (\%). 
a

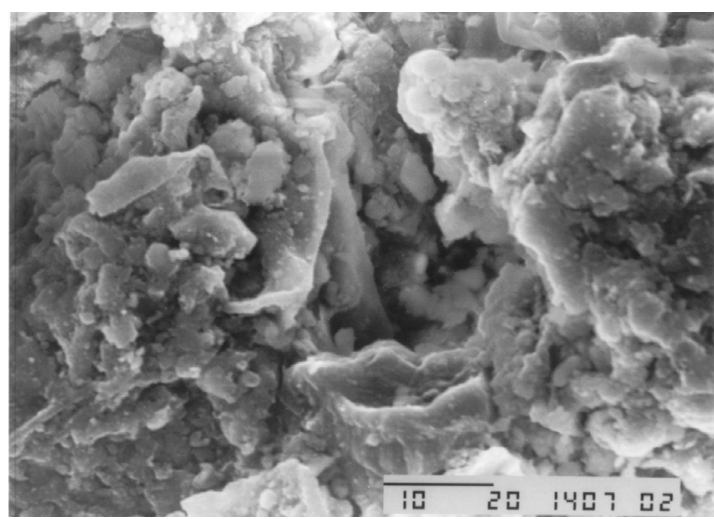

b

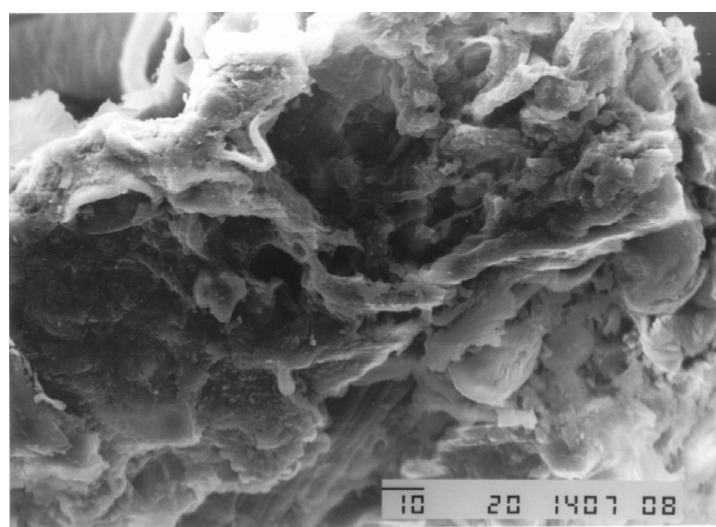

C

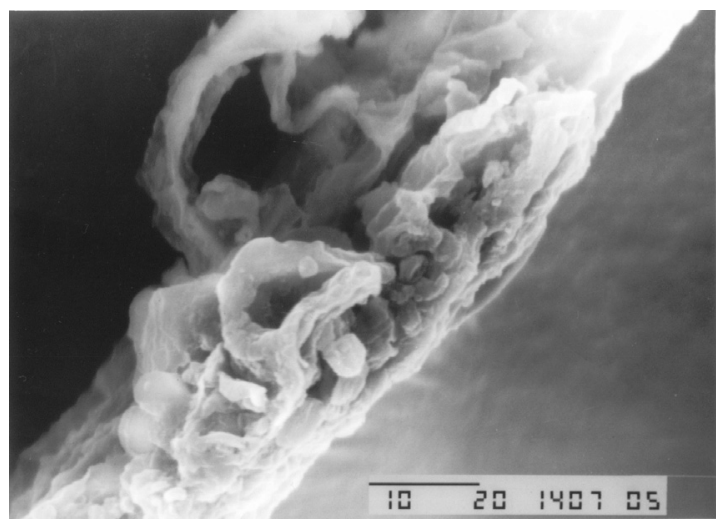

Figure 5. Electron micrograph of (a) $\mathrm{MH}$, (b) SM and (c) XA, with magnifications of 2000, 750 and 2000 times, respectively.

$\left(\mathrm{mg} \mathrm{g}^{-1}\right) ; \mathrm{a}=$ constant, related to adsorption energy, and expressed by equation:

$b_{o} \exp (-\Delta H / R T)$

Here, $\mathrm{b}_{\mathrm{o}}=$ constant, including the entropy term, $\mathrm{R}=$ universal gas constant, $\mathrm{T}=$ absolute temperature. This constant (a) can be expressed as $\mathrm{L} \mathrm{mg}^{-1} ; \mathrm{b}=$ highest metal adsorption capacity in the vermicompost $\left(\mathrm{mg} \mathrm{g}^{-1}\right) ; \mathrm{C}_{\mathrm{eq}} \mathrm{M}=$ equilibrium metal concentration $\left(\mathrm{mg} \mathrm{L}^{-1}\right)$.

According to the literature, ${ }^{14}$ equation 1 can be linearized, yielding equation 3 :

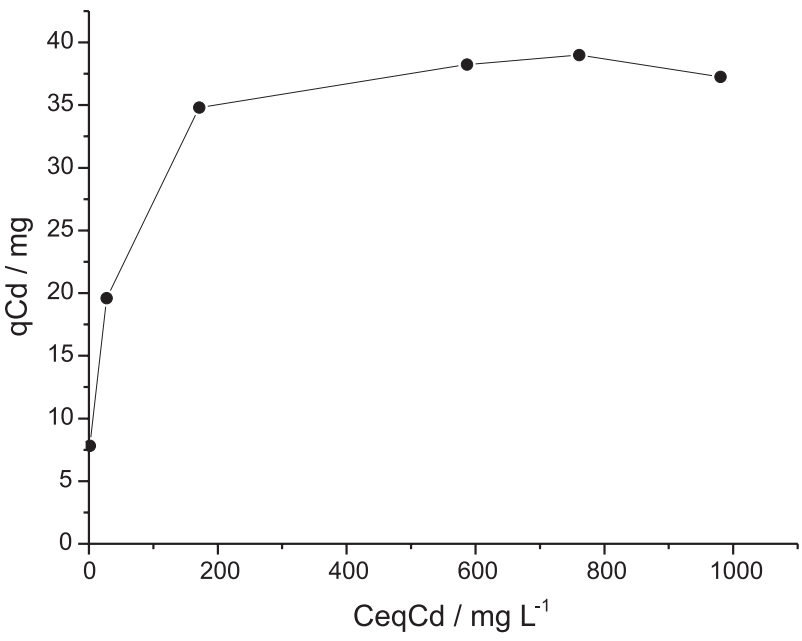

Figure 6. Langmuir isotherm for cadmium, where $\mathrm{qCd}$ is the quantity of cadmium adsorbed in vermicompost and $\mathrm{CeqCd}$ is the equilibrium cadmium concentration.

$C_{e q} M / q M=(a \cdot b)^{-1}+(b)^{-1} \cdot C_{e q} M$

From the inverse of the angular coefficient indicated in Figure 7 (linearization of the results from Figure 6), it is possible to calculate the maximum adsorption capacity for cadmium in the vermicompost $\left(38.6 \mathrm{mg} \mathrm{g}^{-1}\right)$. When compared to different adsorbent materials, ${ }^{15}$ vermicompost presents an expressive cadmium adsorption capacity.

In the pre-concentration experiments, it was possible to confirm the cadmium adsorption potential of vermicompost, because this material exhibited both high enrichment factor (EF) and pronounced recovery for synthetic and real samples. According to the literature, ${ }^{16}$ $\mathrm{EF}$ values can be calculated from the ratio of sample and the elution volume. In the present work, an EF of 100 was obtained. Based on this same reference, ${ }^{16}$ cadmium

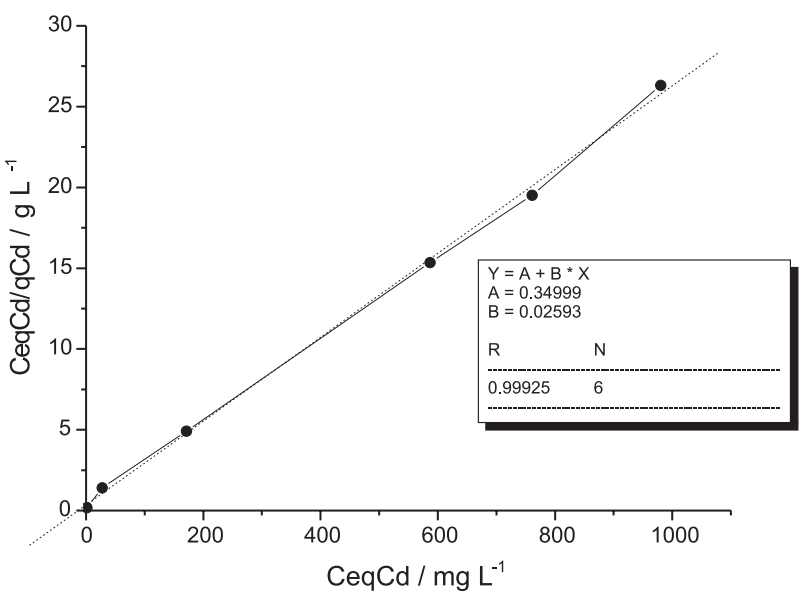

Figure 7. Linearization of Langmuir isotherm for cadmium, where $\mathrm{CeqCd} / \mathrm{qCd}$ is the ratio between the equilibrium concentration and the quantity of cadmium adsorbed in vermicompost. 
recoveries were calculated from the ratio between the cadmium concentration found by FAAS (pre-concentrated samples) and that concentrations seen in the synthetic or real samples after their preparation or enrichment with $5 \mu \mathrm{g} \mathrm{L}^{-1} \mathrm{Cd}$ respectively. The cadmium concentration determined by GFAAS in the synthetic solution after its preparation was $4.76 \pm 0.06 \mu \mathrm{g} \mathrm{L}^{-1}$, whereas the concentration of this metal in the eluent solutions $(10 \mathrm{~mL}$ of $1.0 \mathrm{~mol} \mathrm{~L}^{-1} \mathrm{HNO}_{3}$ ) was $456 \pm 23 \mu \mathrm{g} \mathrm{L}^{-1}$ (determination by FAAS). Thus, a recovery of $c a .96 \%$ was observed. For real samples (mineral waters enriched with $\mathrm{Cd}$ ), the eluent solutions presented Cd concentrations of $479 \pm 31 \mu \mathrm{g} \mathrm{L}^{-1}$, while in directly determined samples, the $\mathrm{Cd}$ concentration value was $4.84 \pm 0.04 \mu \mathrm{g} \mathrm{L}^{-1}$. Therefore, a recovery of $99 \%$ was calculated. As additional information, the natural concentration of $\mathrm{Cd}$ in mineral water was always below the detection limit of the GFAAS technique $\left(<0.17 \mu \mathrm{g} \mathrm{L}^{-1}\right)$.

It was necessary to use a vermicompost mass of at least $120 \mathrm{mg}$ in order to compensate the competition effects between $\mathrm{Cd}^{2+}$ and the main constituents of mineral waters [Ca, $\mathrm{Mg}, \mathrm{K}$ at 13.4, 5.0, $1.9 \mathrm{mg} \mathrm{L}^{-1}$ (determined by FAAS/ FAES) and $\mathrm{Na}$ at $10.2 \mathrm{mg} \mathrm{L}^{-1}$, as indicated in the label]. When $60 \mathrm{mg}$ of vermicompost were used for real samples, recoveries between 50 and $60 \%$ were verified. In the synthetic sample (without concomitants ions) a vermicompost mass of $60 \mathrm{mg}$ was sufficient for quantitative recovery of cadmium.

\section{Conclusions}

This work presents data to support the applicability of vermicompost in adsorptive processes. The results highlight vermicompost as a potential material for cadmium adsorption. For cadmium preconcentration procedures, this potential was confirmed, as high pre-concentration factors and recoveries were obtained. This characteristic is of high analytical interest, as vermicompost is easily available at low cost ( $c a$. US\$ 100 per ton).

Related to adsorption behavior, it is possible to predict that vermicompost may adsorb other metallic species as efficiently as $\mathrm{Cd}^{2+}$. This affirmative is based on the structural properties of vermicompost, as this material demonstrates desirable characteristics (e.g., high CEC values), which can be applicable to different metals. In this way, studies should be carried out to investigate the use of this material in relation to the adsorption of other metals.

According to all these characteristics, use of vermicompost for determination of environmental contaminants is feasible; mainly those related to determining the results of treatments of effluents heavy high initial metal concentrations.
For environmental purposes, when complex matrices are considered, an increase in the vermicompost mass could be made to compensate possible differences in the adsorption properties due to the presence of concomitants.

\section{Acknowledgements}

Partial support and grants from the Conselho Nacional de Desenvolvimento Científico e Tecnológico (CNPq, Brasília, Brazil) and Fundação de Amparo à Pesquisa do Estado de São Paulo (FAPESP, São Paulo, Brazil - grant number 99/12124-7) are greatly appreciated. The authors are grateful to Prof. Elias A. G. Zagatto and Prof. Carol H. Collins for language improvement, and to E. R. PereiraFilho for computational support.

\section{References}

1. Landgraf, M. D.; da Silva, S. C.; Rezende, M. O. O.; Anal. Chim. Acta 1998, 368, 155.

2. Rashid, M. A.; Geochemistry of Marine Humic Compounds, $1^{\text {st }}$ ed.; Springer-Verlag: Berlin, 1985

3. Ro, K. S.; Preston, K. T.; Seiden, S.; Bergs, M. A.; Crit. Rev. Environ. Sci. Technol. 1998, 28, 253.

4. Stanley, E. M.; Environmental Chemistry, $6^{\text {th }}$ ed.; Lewis Publishers: London, 1994.

5. Pace, A. L.; Miller, R. H.; Keeney, D. R.; Methods of Soil Analysis, Part 2 - Chemical and Microbiological Properties, $2^{\text {nd }}$ ed.; Soil Science Society of America, Inc. Publisher: Madison, 1982.

6. Magalhães, C. E. C.; Pasquini, C.; Arruda, M. A. Z.; Lab. Rob. Autom. 2000, 12, 46.

7. Matthias, O.; Chemometrics - Statistics and Computer Application in Analytical Chemistry, Wiley-VCH: Weinheim, 1999.

8. Slavek J.; Wold, J.; Pickering, W. F.; Talanta 1982, $29,743$.

9. Lamim, S. S. M.; Jordão, C. P.; Brune, W.; Pereira, J. L.; Bellato, C. R.; Quim. Nova 1996, 19, 457.

10. Rocha, J. C.; Rosa, A. H.; Furlan, M.; J. Braz. Chem. Soc. 1998, 9, 51.

11. Wershaw, R. L.; Pinckney, D. J.; Anal. Chim. Acta 1990, $232,31$.

12. Pavia, D. L.; Lampman, G. M.; Kriz, G. S.; Introduction to Spectroscopy, $2^{\text {nd }}$ ed., Harcourt Brace College Publishers: Philadelphia, 1996.

13. Sag, Y.; Kutsal, T.; Biochem. Eng. J. 2000, 6, 145.

14. Hseih, C. T.; Teng, H.; Carbon 2000, 38, 863.

15. Kaewsam, P.; Yu, Q.; Environ. Pollut. 2001, 112, 209.

16. Bag, H.; Lale M.; Türker, A. R.; Talanta 1998, 47, 689.

Received: December 14, 2001

Published on the web: November 29, 2002 